\title{
Controls and Implications of Geo-Technical Variation in Quartzose Rocks from Peshawar Basin, North-Western Pakistan
}

\author{
Khan Zada1, Mohammad Arif ${ }^{2,3^{*}}$, Muhammad Sajid ${ }^{2}$ \\ ${ }^{1}$ Geo-Technical and Geo-Environmental Engineering Division, NESPAK, Lahore, Pakistan \\ ${ }^{2}$ Department of Geology, University of Peshawar, Peshawar, Pakistan \\ ${ }^{3}$ Department of Earth Sciences, CIIT, Abbottabad, Pakistan \\ Email: ${ }^{*}$ arif pkpk@yahoo.com
}

Received 23 August 2015; accepted 9 October 2015; published 12 October 2015

Copyright (C) 2015 by authors and Scientific Research Publishing Inc.

This work is licensed under the Creative Commons Attribution International License (CC BY). http://creativecommons.org/licenses/by/4.0/

(c) (7) Open Access

\begin{abstract}
Petrographic and geo-mechanical properties of samples representing quartzose rocks of Tanawal Formation (Baja Bamkhel area, Swabi) and Misri Banda quartzite (Nowshera) from Peshawar Basin, NW Pakistan, have been investigated. Although formerly referred to as quartzite, mineralogical composition and textural details support characterization of the studied quartzose samples of Tanawal Formation as blasto-psammite and those of Misri Banda as sub-arkose. The two rock types also show significant differences in terms of matrix and heavy mineral concentrations as well as the degree and frequency of intra-granular deformation. On the basis of unconfined compressive strength (UCS), both fall in the category of very strong rocks. Correspondingly, their specific gravity and water absorption values are high and low respectively and lie well within the range permissible for use as construction material. However, both contain high amounts of deleterious components, i.e. reactive forms of silica (chert and/or strained quartz) and clay minerals. Therefore, they cannot be used as coarse aggregate with Ordinary Portland Cement (OPC) and asphalt. The modal abundance of quartz is higher in the Misri Banda than the Tanawal samples, but the quartz to feldspar ratios are higher for the latter. Yet, the sub-arkosic Misri Banda rocks are stronger than the Tanawal blasto-psammites, most probably because they are i) almost totally devoid of matrix; ii) finer grained; iii) having a higher percentage of grains with irregular and sutured contacts and iv) lesser abundance of grains displaying intra-granular deformation.
\end{abstract}

\section{Keywords}

Quartzose Rocks, Petrography, Strength, Physical Properties, Geo-Technical Feasibility

\footnotetext{
*Corresponding author.
}

How to cite this paper: Zada, K., Arif, M. and Sajid, M. (2015) Controls and Implications of Geo-Technical Variation in Quartzose Rocks from Peshawar Basin, North-Western Pakistan. Geomaterials, 5, 85-98. 


\section{Introduction}

The areas under the current investigation lie in the south-eastern part of the Peshawar Basin, NW Pakistan. The Peshawar Basin is piggyback-type since it has been carried passively on the back of low-angle detachment faults and thrust sheets, some of which are exposed at the surface in the hill ranges to the south [1]. The Peshawar Basin is surrounded by low hill ranges comprising of Precambrian metasedimentary rocks and an almost complete Paleozoic sequence, which is fossiliferous (Figure 1) [2] [3]. The aim of the present study is to present an account of the petrographic and geo-mechanical characteristics of representative samples of Tanawal Formation and Misri Banda quartzite of the Peshawar Basin. The results obtained are analyzed for i) petrographic characterization; ii) assessment of geo-technical utility; and iii) provenance determination. As the rock strength and physical properties rely on modal mineralogical composition and textural characteristics [4]-[10], an attempt has also been made to look into variation in mechanical properties and explain it in the light of petrographic details.

\section{Regional Tectonics and Stratigraphy}

The Cenozoic collision between the Indian and Eurasian plates has produced one of the most distinctive global features, i.e. the Himalayan mountain belt. Volcanism, magmatism and associated metamorphism are the characteristic outcomes of this gigantic collision [11]. The gradual release of the north-south oriented compressive stresses developed in the course of the collision has resulted in extensive deformation leading to the formation of south-verging fold-and-thrust belts along the northern margin of the Indo-Pakistan tectonic plate [12]. The northwest Himalayan fold-and-thrust belt includes all the terrain between the Main Mantle Thrust (MMT) in the north and the Salt Range Thrust (SRT) in the south [11]. As such, the tectonic setting of the Peshawar Basin is transitional between a sedimentary fold and thrust belt to the south and metamorphic terrain to the north [2]. The grade of metamorphism and intensity of deformation both gradually increase from south to north across the Peshawar Basin.

The basal Proterozoic sedimentary sequence of the Peshawar Basin consists of the Hazara (Dakhner), Gandaf, Manki and Tanawal formations, which is overlain by the Paleozoic sequence that includes the Ambar, Misri Banda, Panjpir, Nowshera, Jafar Kandao and Duma Formations Table 1 [2] [3] [13]. The almost complete Paleozoic sequence is exposed in the ranges that fringe the Peshawar Basin [13] [14]. The study areas lie in the

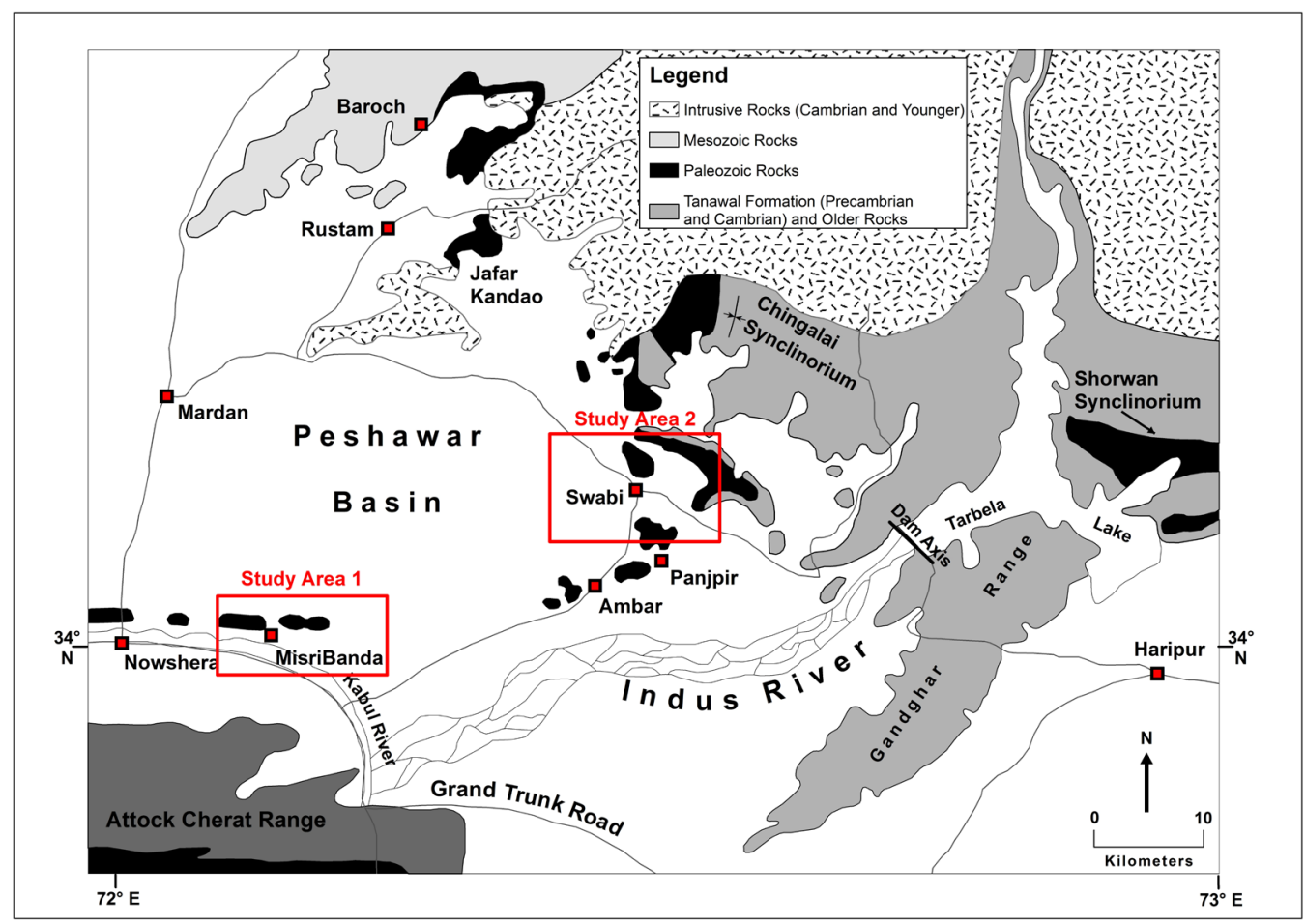

Figure 1. A generalized geological map of eastern Peshawar Basin showing the study areas [14]. 
Table 1. The early Proterozoic to Mesozoic stratigraphy of the Peshawar Basin, NW Pakistan [2].

\begin{tabular}{cc}
\hline Age & Formation \\
\hline Mesozoic & Nikanai Ghar \\
\hline Late Paleozoic-Triassic & Karapa Greenschist \\
\hline Early-Middle Paleozoic & Jafar Kandao \\
\hline Late Proterozoic & Nowshera \\
\hline Early Proterozoic & Panjpir \\
\hline
\end{tabular}

south-eastern part of the Peshawar Basin and contain Tanawal Formation, Ambar Formation, Misri Banda quartzite, Panjpir and Nowshera Formations of early-middle Paleozoic age [14].

\section{Methodology}

Fresh (unaltered) bulk and fist-sized rock samples were collected. Two of the three bulk samples collected for determining physical and mechanical properties represent the Baja Bamkhel (Swabi) section of Tanawal Formation, while the third one is from the quartzose rocks exposed around Misri Banda village (Nowshera). Following the standard specifications [15], three cylindrical and three disc-shaped core samples for determining unconfined compressive strength (UCS) and unconfined tensile strength (UTS), respectively were obtained from each of the bulk samples with the help of a core drilling machine. The shear strength of the rocks was measured indirectly using the values of UCS and UTS. Furthermore, specific gravity and capacity of water absorption of the samples were determined in accordance with standard specifications [16]. Two standard rock thin sections per core sample were used for a detailed examination employing a transmitted light petrographic microscope.

\section{Petrography}

Following observations in the field and hand samples, representative rock thin sections were used for a detailed petrographic investigation including structural/textural characteristics, identification of the constituent minerals, and determination of modal mineralogical composition through visual estimation. Based on these details, the studied samples from Tanawal Formation are distinguished into two textural and mineralogical types: i) blasto-psammite and ii) blasto-pelite. In the same manner, the specimens from Misri Banda are classified as subarkose. The petrographic features of the three rock types are described below.

\subsection{Blasto-Psammite (Tanawal Formation)}

The thick bedded Tanawal blasto-psammite is inequi-granular (poorly sorted) and contains rounded to sub-angular and sub-prismoidal to sub-spherical grains. The framework constituents include abundant quartz (79 - 86 modal \%) and accessory amounts (1 - 3 modal \%) of tourmalines displaying different colours, muscovite, opaque (magnetite) and reddish brown (hematite) ore minerals and chert fragments (Figure 2(a)), and traces ( $\leq 1$ modal \%) of feldspar, monazite and, rather rarely, zircon Table 2. The matrix (5 - 11 modal \%) consists of a fine intergrowth of abundant fine-grained sericite and subordinate silt-size quartz (Figure 2(b)). Most of the framework quartz is medium-grained; only a minor proportion occurs as small and large grains that are randomly distributed among the medium-sized grains (Figure 2(b)). The relatively larger quartz grains contain intra-granular fractures and/or display patchy or undulose/wavy extinction due to distortion in crystal lattice (i.e. development of dislocations or defects) resulting from strain-induced intra-crystalline deformation (Figure 2(c)-(e)). The tourmaline also displays intra-granular fracturing (Figure 2(f)). Most of the quartz grains are monocrystalline, 


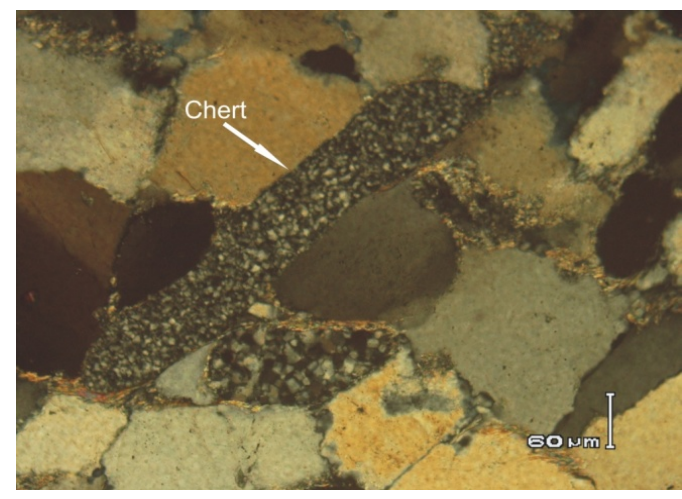

(a)

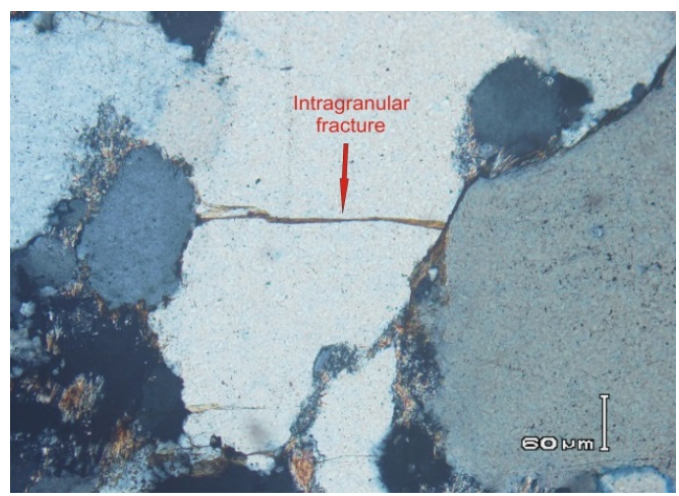

(c)

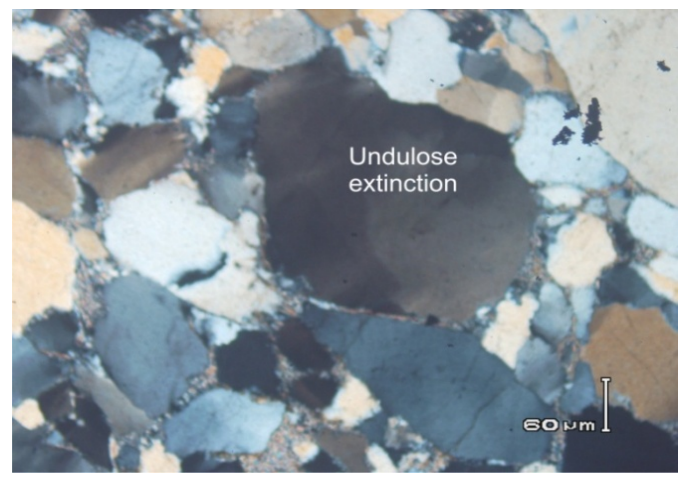

(e)

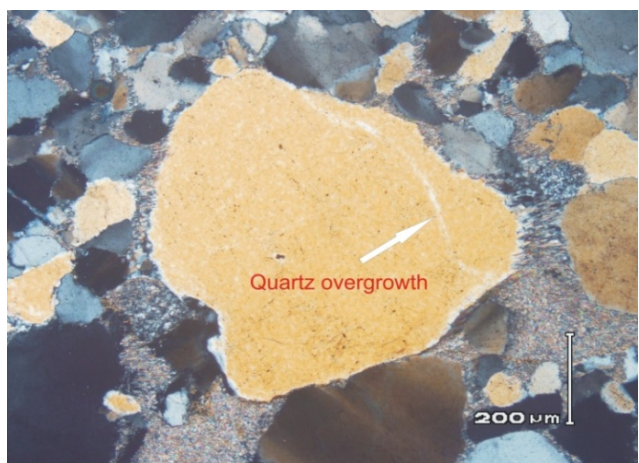

(g)

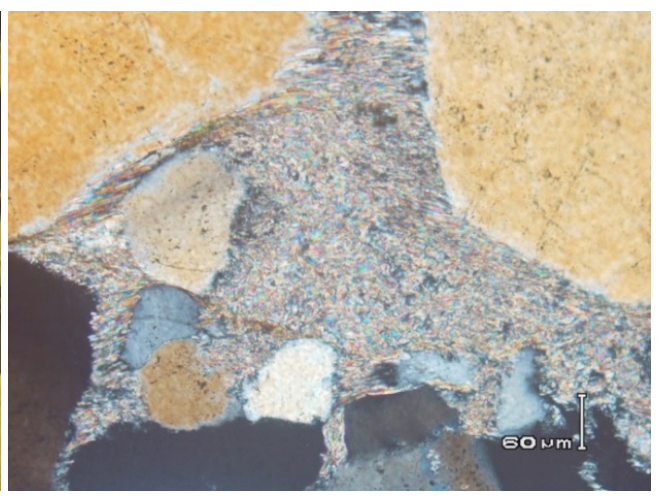

(b)

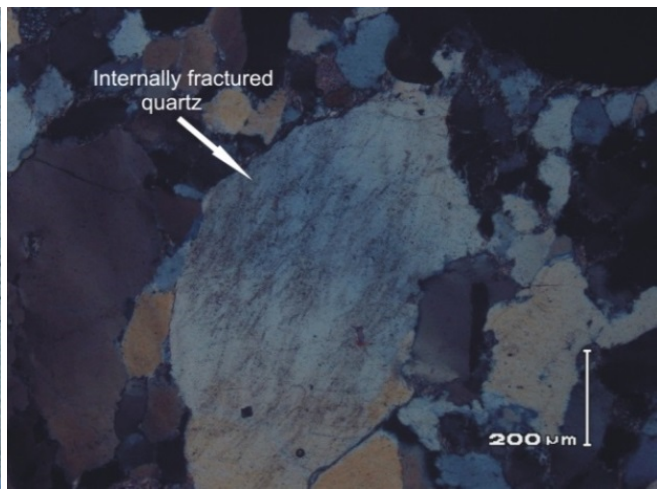

(d)

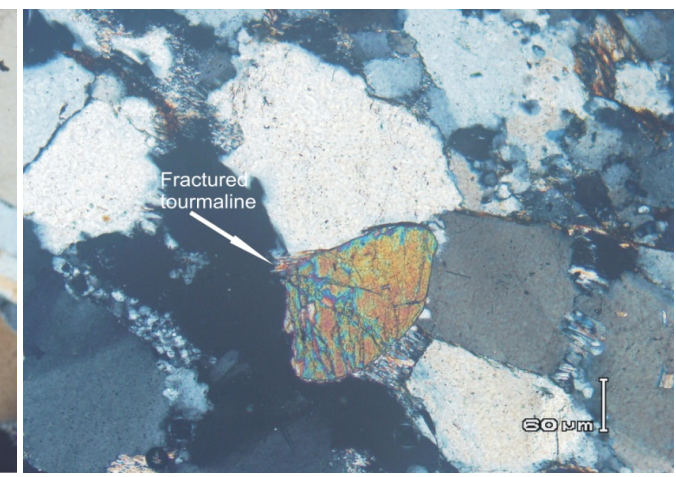

(f)

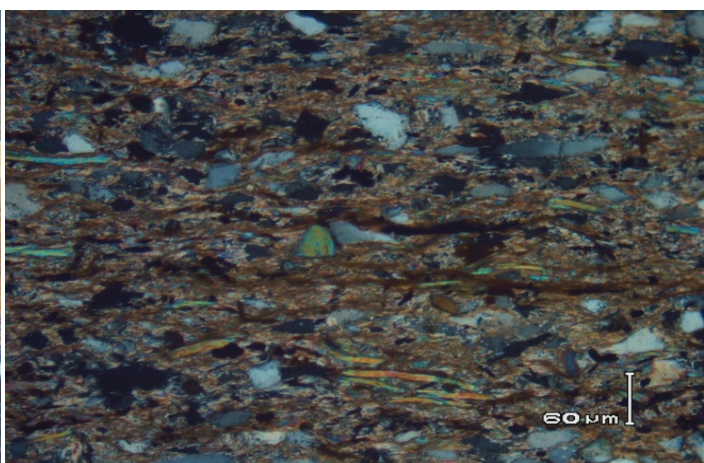

(h)

Figure 2. Photomicrographs showing important petrographic features in the investigated samples of blastopsammite (a)-(g) and blasto-pelite (f) representing Tanawal Formation. See text for details. 
Table 2. Modal mineralogical composition of quartzose rocks from Tanawal (TQ) and Misri Banda (MQ), Peshawar Basin, NW Pakistan.

\begin{tabular}{|c|c|c|c|c|c|c|c|c|c|}
\hline Sample & Quartz & Feldspar & Lithics & Muscovite & Tourmaline & Monazite & Zircon & Ore & Matrix \\
\hline TQ1a & 86 & 1 & 1 & 1 & 2 & 1 & - & 1 & 7 \\
\hline TQ1b & 83 & 1 & 2 & 2 & 2 & - & - & 1 & 9 \\
\hline TQ1c & 86 & - & 2 & 1 & 3 & 1 & - & 2 & 5 \\
\hline TQ2a & 85 & 1 & 1 & 2 & 2 & - & - & 2 & 7 \\
\hline TQ2b & 79 & 1 & 2 & 2 & 2 & - & 1 & 2 & 11 \\
\hline TQ2c & 83 & 1 & 1 & 1 & 2 & 1 & - & 1 & 8 \\
\hline MQ1a & 86 & 8 & 2 & 1 & - & - & 1 & 2 & - \\
\hline MQ1b & 88 & 7 & 1 & 2 & - & 1 & - & 1 & - \\
\hline MQ1c & 90 & 6 & - & 1 & - & 1 & - & 1 & 1 \\
\hline
\end{tabular}

however, polycrystalline quartz grains also occur. Some of the quartz grains display sutured boundaries; outlines of most of the others are more or less straight. Development of quartz overgrowth is also a more or less commonly observed feature (Figure 2(g)). Most of the feldspar grains are altered and hence their original textural features are not readily recognizable.

\subsection{Blasto-Pelite (Tanawal Formation)}

Previously described as Tanawal quartz-mica schist, the rock under discussion occurs as subordinate thin bedded to laminated horizons, interbedded with the thick-bedded to massive Tanawal blasto-psammite. The blasto-pelite is markedly different from blasto-psammite in terms of both modal mineralogy and textural/structural features. It essentially contains fine grained quartz (45 modal \%) and thin long flakes of muscovite (25 modal \%) as framework constituents. Tourmaline, zircon and ore minerals are present as accessory phases. These detrital components are distributed in a sericite-dominated matrix that ranges up to 20 modal \% (Figure 2(h)). The relative proportion of sericite is significantly higher than that in blastopsammite. Muscovite occurs as short and long flakes displaying preferred orientation thereby imparting the rock a foliated character. Most of the quartz grains are flattened and even somewhat elongated and thereby aligned along the planes of foliation. Owing to these features, the blasto-pelite breaks readily into thin flakes with smooth and planar surfaces. That is why the geotechnical properties (i.e. UCS, UTS, shear strength, water absorption and specific gravity) of this evidently weak rock were not determined during the current investigation.

\subsection{Sub-Arkose (Misri Banda)}

These very hard and compact rocks exhibit light gray to pinkish gray color in the outcrop and hand specimen. The studied samples are more or less equi-granular (i.e. moderately well sorted; Figure 3(a)) and consist of particles with sub-angular to sub-rounded outlines. Whereas most of them are almost totally free of matrix, some do contain ferruginous cement/ matrix in trace amounts (up to 1\%; Figure 3(b)). Medium-grained quartz (86\% 90\%) and feldspars including plagioclase and alkali feldspar (5\% - 8\% modal \%) are their essential framework constituents while rock fragments, i.e. chert (1\% - 2\%; Figure 3(c)), muscovite, biotite, zircon, monazite, and grains of an opaque ore are the commonly occurring accessory minerals. Although most of the quartz grains display uniform extinction, the rarely occurring larger quartz grains show undulose extinction and/or sutured contacts (Figure 3(d), Figure 3(e)). Some of the quartz grains display overgrowths (Figure 3(f)). A relatively smaller proportion of quartz occurs as polycrystalline grains. Whereas most of the fine and medium-sized quartz grains are free of inclusions, the relatively larger ones contain inclusions of accessory minerals.

Alkali feldspar and plagioclase occur more or less commonly in the studied thin sections. The alkali feldspar appears to be more abundant than plagioclase and includes both orthoclase and microcline. The latter shows the typical scotch plaid twinning (Figure 3(g)). On the other hand, the plagioclase grains commonly display the diagnostic albite-polysynthetic twinning (Figure 3(h)). 


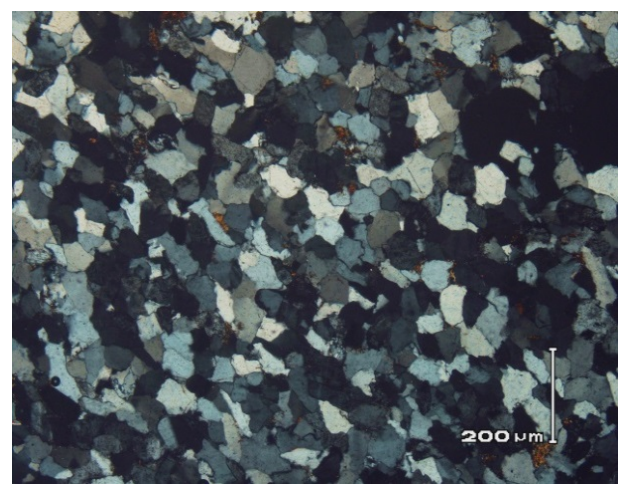

(a)

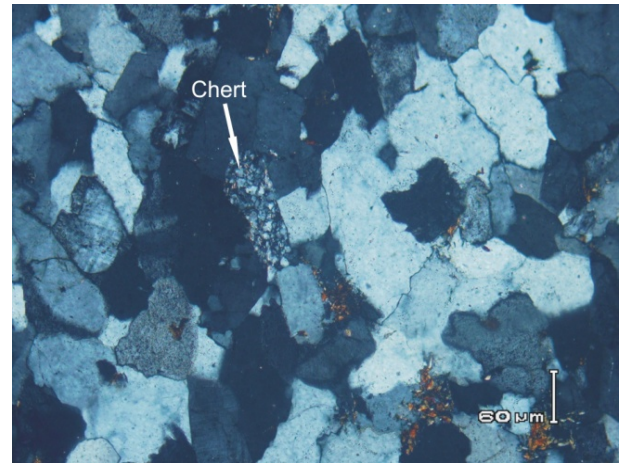

(c)

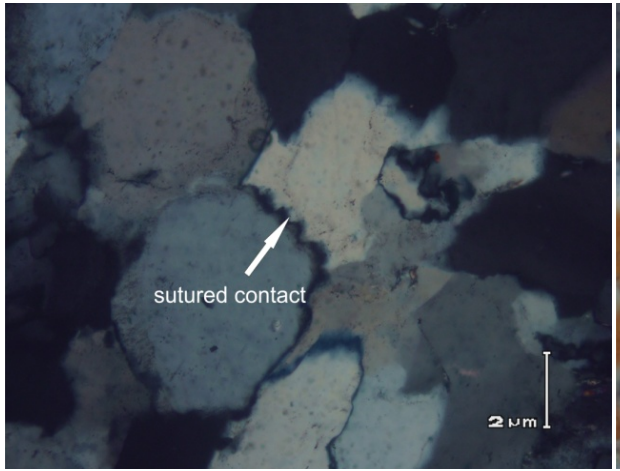

(e)

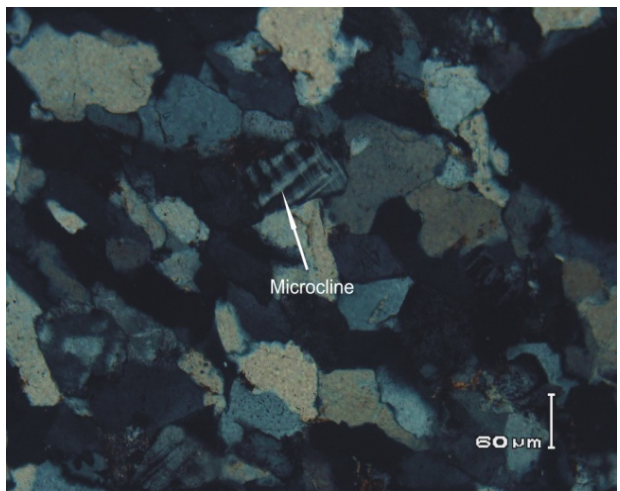

(g)

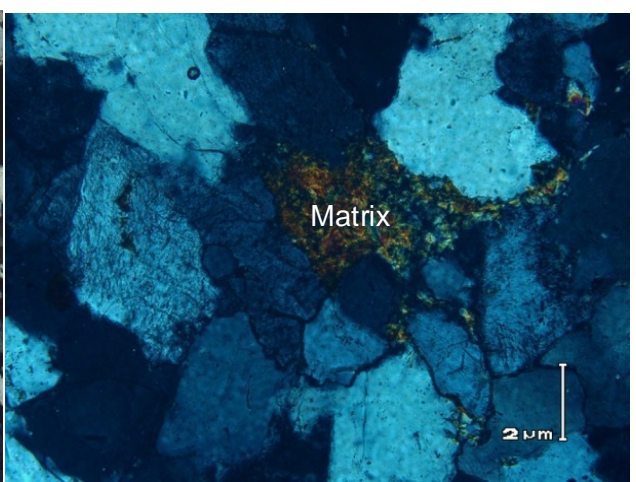

(b)

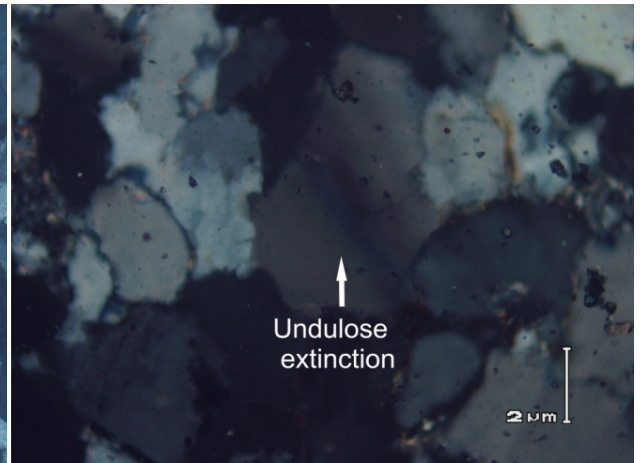

(d)

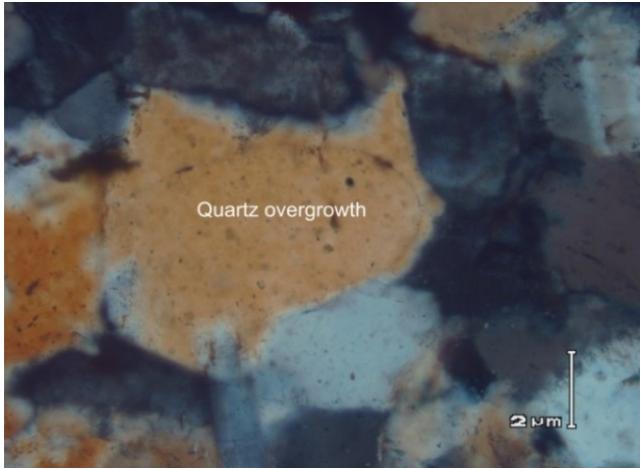

(f)

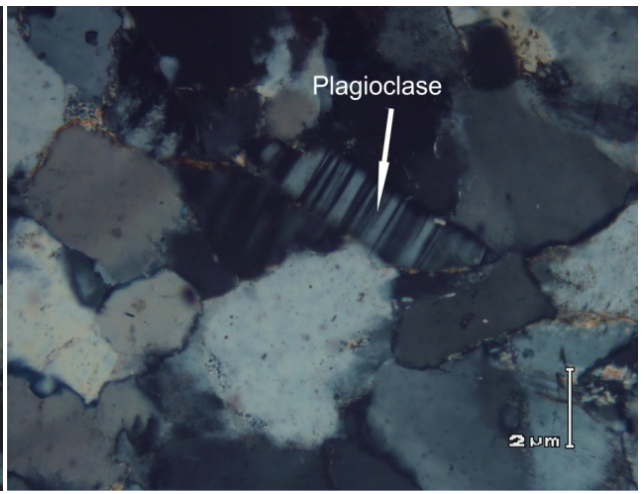

(h)

Figure 3. Photomicrographs showing important petrographic features in the investigated samples of sub-arkose from Misri Banda. See text for details. 


\section{Mechanical and Physical Properties}

\subsection{Strength}

The UCS and UTS of the petrographically investigated samples of Tanawal balsto-psammite (quartz arenite) and Misri-Banda quartzite (sub-arkose) were determined in the laboratory. Besides, the values of shear strength of both these rocks were calculated. The UCS and UTS values were measured directly using strength testing machine, while cohesion and angle of internal friction, which collectively determine shear strength, were derived from the values of UCS and UTS employing the method described previously e.g. [17].

Three core samples per bulk sample were used for determining the UCS and UTS. The values of UCS of all the studied rocks are high enough (115.8 - 155.9 MPa) Table 3 to group them with those categorized as very strong [18].

\subsection{Water Absorption}

Determination of water absorption is important as repeated hydration and dehydration result in mechanical disruption of small portions of rock close to an exposed surface and allows access of water into the rock and thus causing an increase in the degree and rate of weathering [9]. Employing the method and calculations described elsewhere [19], the values of water absorption for both the Tanawal and Misri Banda samples were determined Table 3.

\subsection{Specific Gravity}

The feasibility of rocks for construction purposes depends on their specific gravity and it is believed that rocks with specific gravity $\geq 2.55$ are suitable for use in heavy construction work [20]. The specific gravity of the Tanawal and Misri Banda samples was determined in the laboratory using the equipment and formula mentioned elsewhere [19]. The values obtained are given in Table 3.

\section{Discussion}

\subsection{Petrographic Characterization}

Quartzose rocks from both the Tanawal and Misri Banda Formations are indifferently referred to as quartzite in the relevant published literature. However, the modal composition of the studied samples from Misri Banda falls in the field of sub-arkose rather than quartz arenite Table 2 (Figure 4). Similarly, the petrographic details of samples representing the thick bedded to massive horizons of the Tanawal Formation are suggestive of their characterization as quartz-rich blasto-psammite Table 2 (Figure 4). The modal compositions of all the blastopsammite samples fall in the field of quartz arenite (Figure 4). In addition to the type and relative proportions of framework constituents and matrix, the investigated rocks from the two study areas also differ markedly in terms of their textural details, especially the degree of sorting, and size/shape, degree of angularity/roundness and

Table 3. Strength and physical properties of the studied samples.

\begin{tabular}{|c|c|c|c|c|c|c|c|c|}
\hline Area/Formation & Sample ID & UCS (MPa) & UTS (MPa) & $\begin{array}{l}\text { UCS to UTS } \\
\text { Ratio }\end{array}$ & $\begin{array}{l}\text { Cohesion } \\
\text { (MPa) }\end{array}$ & $\begin{array}{l}\text { Angle of Internal } \\
\text { Friction (Ф) }\end{array}$ & $\begin{array}{c}\text { Water Absorption } \\
(\%)\end{array}$ & $\begin{array}{l}\text { Specific } \\
\text { Gravity }\end{array}$ \\
\hline \multirow{6}{*}{ 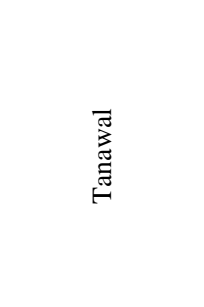 } & TQ1a & 122.65 & 13.33 & 9.20 & 19.68 & 52.81 & 0.593 & 2.568 \\
\hline & TQ1b & 122.19 & 12.72 & 9.61 & 19.56 & 54.45 & 0.386 & 2.578 \\
\hline & TQ1a & 123.23 & 13.59 & 9.07 & 20.28 & 53.16 & 0.231 & 2.603 \\
\hline & TQ2a & 120.97 & 15.4 & 7.86 & 21.36 & 50.07 & 0.531 & 2.567 \\
\hline & TQ2b & 115.82 & 15.76 & 7.35 & 20.52 & 48.43 & 0.425 & 2.562 \\
\hline & TQ2c & 119.88 & 16.39 & 7.31 & 22.20 & 49.59 & 0.643 & 2.558 \\
\hline \multirow{3}{*}{ 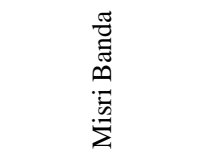 } & MQ1a & 155.09 & 24.39 & 6.36 & 31.44 & 47.41 & 0.097 & 2.648 \\
\hline & MQ1b & 155.93 & 24.55 & 6.35 & 30.72 & 46.78 & 0.078 & 2.647 \\
\hline & MQ1c & 154.84 & 24.62 & 6.29 & 28.8 & 45.91 & 0.076 & 2.646 \\
\hline
\end{tabular}




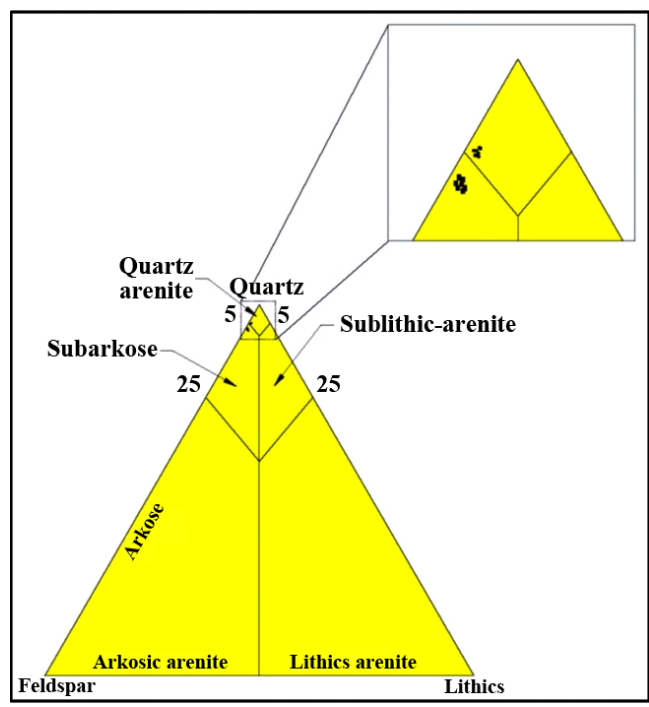

Figure 4. Modal composition of blasto-psammite from Tanawal Formation and sub-arkose from Misri Banda plotted on the quartz-feldspar-lithics triangular diagram [21] [22].

inter-grain boundaries of their framework constituents Table 2 and Table 4 (Figure 2 and Figure 3). Besides, the Tanawal samples are coarser grained and contain grains with features suggestive of both brittle and ductile intra-crystalline deformation, i.e. intra-granular cracks/fractures and undulose/patchy extinction, respectively.

In addition to containing different amounts of essential minerals, the investigated quartzose rocks from the two areas also differ significantly in terms of the type and abundance of their accessory and minor constituents Table 2 and Table 4. In addition to being almost totally free of matrix, the Misri Banda sub-arkose does not contain tourmaline. Although the overall abundance of quartz is greater in the Misri Banda than the Tanawal samples, the distinctly higher amounts of feldspars make the former display markedly lower quartz to feldspar ratio Table 2 and Table 4.

\subsection{Relationship between Geo-Technical and Petrographic Properties}

The investigated rock types differ significantly in terms of their strength. However, the UCS values of all of them fall within the range of those designated as very strong Table 3 [18]. Similarly, the values of their water absorption are low and specific gravity high enough to render them suitable for use as construction material (Table 3).

The various petrographic characteristics generally believed to be controlling the physical and mechanical properties of rocks have been summarized elsewhere [19]. Results and conclusions from relevant previous studies suggest that the geo-mechanical properties of quartzose rocks (sandstones) like the ones under investigation vary widely and depend on several parameters including grain size, degree of interlocking, type and length of grain contact, nature and abundance of cement and/ or matrix, void space and mineralogical composition [7] [23].

The strength values of the Misri Banda sample are higher than those of Tanawal probably because of i) their finer grain size; ii) greater irregularity of their frameworks; iii) rarity of intra-granular deformational features; and iv) paucity of matrix. However, the greater variability in grain size (i.e. poor degree of sorting) and high to very high quartz to feldspar ratio of the Tanawal samples relative to those from Misri Banda Table 2 and Table 4), support greater strength for the former than the latter. In other words, some but not all of the petrographic features support the higher strength values of the Misri Banda samples. Alternatively, the presence of significant amounts of relatively weak sheet silicate (mica including sericite and muscovite) as matrix in the Tanawal samples and the total absence of the same from the Misri Banda sample has probably played a major role in determining the strength of the studied samples.

The water absorption values of the Misri Banda samples are lower and their specific gravity higher than the 
Table 4. Petrographic and geo-technical comparison among the examined samples.

\begin{tabular}{|c|c|c|c|}
\hline Formation/Area & \multicolumn{2}{|c|}{ Tanawal } & Misri Banda \\
\hline Quartz (modal \%) & TQ1 = $83-86(85)$ & TQ2 = $79-85(82)$ & $86-90(88)$ \\
\hline Feldspar (modal \%) & \multicolumn{2}{|c|}{$\sim 1$} & Mostly 5 - 8 (7) \\
\hline Matrix (modal \%) & $\mathrm{TQ} 1=5-9$ & $\mathrm{TQ} 2=7-11$ & $\leq 1(0.3)$ \\
\hline Grain Size & \multicolumn{2}{|c|}{ Medium } & Fine \\
\hline Sorting & \multicolumn{2}{|c|}{ Poor } & Moderate \\
\hline Roundness & \multicolumn{2}{|c|}{ Rounded to sub-rounded and sub-angular } & Sub-angular to sub-rounded \\
\hline Sutured Contacts & \multicolumn{2}{|c|}{$\begin{array}{l}\text { Rare: only some of the larger quartz grains display } \\
\text { sutured contacts }\end{array}$} & More common than in Tanawal samples \\
\hline Intra-granular Fractures & \multicolumn{2}{|c|}{ More common than in Misri Banda samples } & Rare \\
\hline Strained Quartz & \multicolumn{2}{|c|}{$\begin{array}{l}\text { Monocrystalline quartz with undulose extinction } \\
\text { occurs insubstantial amounts }\end{array}$} & $\begin{array}{c}\text { Rare: only some of the larger quartz grains show } \\
\text { undulose extinction }\end{array}$ \\
\hline Polycrystalline Quartz & \multicolumn{2}{|c|}{$\begin{array}{c}\text { More abundant than in Misri Banda samples, but } \\
\text { very rarely containing more than } 2 \text { to } 3 \text { sub-grains } \\
\text { per grain }\end{array}$} & $\begin{array}{l}\text { Present; but the overall abundance is lower and the } \\
\text { number of sub-grains per grain less than Tanawal }\end{array}$ \\
\hline Average UCS (MPa) & $\mathrm{TQ} 1=122.69 \pm 0.52$ & $\mathrm{TQ} 2=118.89 \pm 2.71$ & $155.29 \pm 0.57$ \\
\hline Average UTS (MPa) & $\mathrm{TQ} 1=13.21 \pm 0.45$ & $\mathrm{TQ} 2=15.85 \pm 0.19$ & $24.52 \pm 0.12$ \\
\hline Average Specific Gravity & $\mathrm{TQ} 1=2.583 \pm 0.018$ & $\mathrm{TQ} 2=2.562 \pm 0.045$ & $2.647 \pm 0.001$ \\
\hline Water Absorption (\%) & $\mathrm{TQ} 1=0.403 \pm 0.182$ & $\mathrm{TQ} 2=0.533 \pm 0.182$ & $0.084 \pm 0.012$ \\
\hline
\end{tabular}

Tanawal specimens. Although such a negative correlation between these two parameters is expected, their close correspondence with differences in UCS is significant and supplements the results from strength testing (Figures 5-7).

The six cores from two bulk samples representing the Tanawal blasto-psammite exhibit significant variation among them in terms of the values of their strength, water absorption and specific gravity Table 3. However, this variation seems to be related to their petrographic characteristics, i.e. the modal abundance of matrix and framework constituents, degree of grain boundary irregularity and the extent of intra-granular deformation (Figure 5, Figure 6, Table 4). Accordingly, the three cores from the Misri Banda sample display more or less identical values of strength, water absorption and specific gravity since their petrographic features are almost the same Table 2 and Table 3. That is also why the average values of strength, physical properties and petrographic parameters display strong correlations with one another (Figure 7).

\section{Conclusions}

1) Petrographic details suggest the characterization of the studied samples from Misri Banda and Tanawal Formation as sub-arkose and quartz-rich blasto-psammite, respectively.

2) The optical properties of quartz, the relative abundance of different types of quartz grains and the nature of heavy minerals indicate a plutonic igneous source for the Misri Banda sub-arkose, but a metamorphic source for the Tanawal blasto-psammite. However, the presence of different colour varieties of tourmaline suggest granitic to pegmatitic protolith for the metamorphic source of the Tanawal sediments.

3) On the basis of UCS and UTS, all the studied samples fall in the category of very strong rocks. Correspondingly, the values of their specific gravity and water absorption are within the range permissible for their use as construction material. However, the presence of deleterious/reactive and hydrophilic material i.e. chert, strained quartz and/or clay minerals, makes the material represented by the studied samples unsuitable for use as coarse aggregate with Ordinary Portland Cement (OPC) and asphalt.

4) The Misri Banda samples are stronger than the Tanawal blasto-psammite most probably due to i) the lack of matrix; ii) their finer grain size and iii) higher percentage of grains with irregular and sutured contacts as compared to the Tanawal blasto-psammite. 

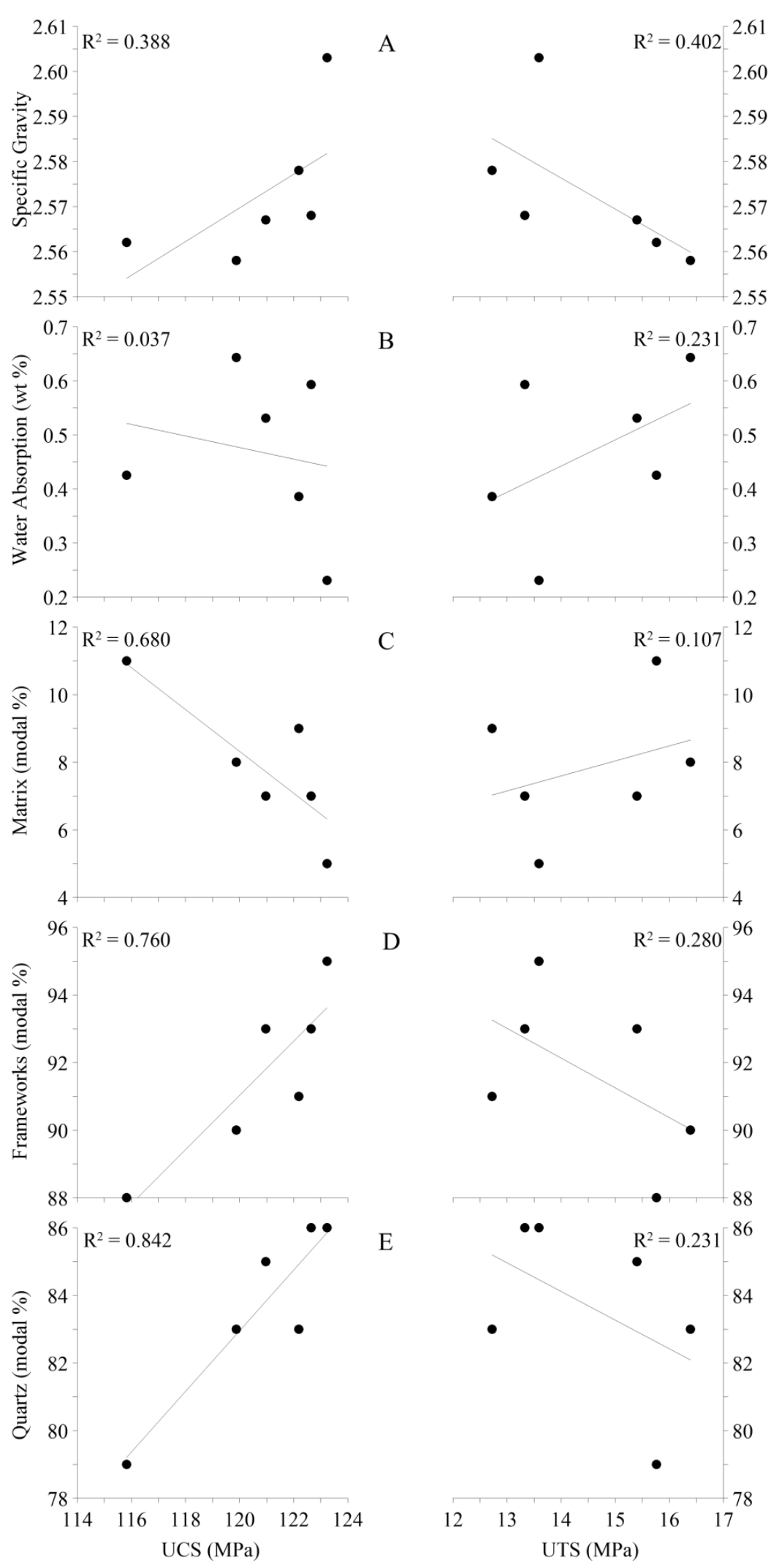

Figure 5. Variation of strength with petrographic and physical properties of the Tanawal samples. 


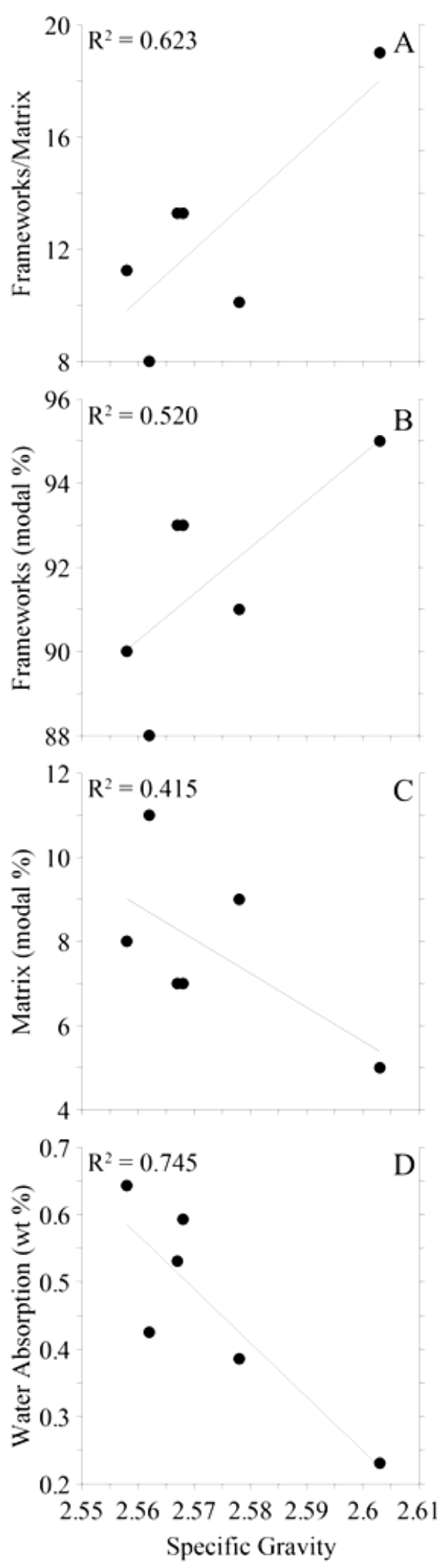

Figure 6. Relation of specific gravity with petrographic properties and water absorption of the Tanawal samples. 


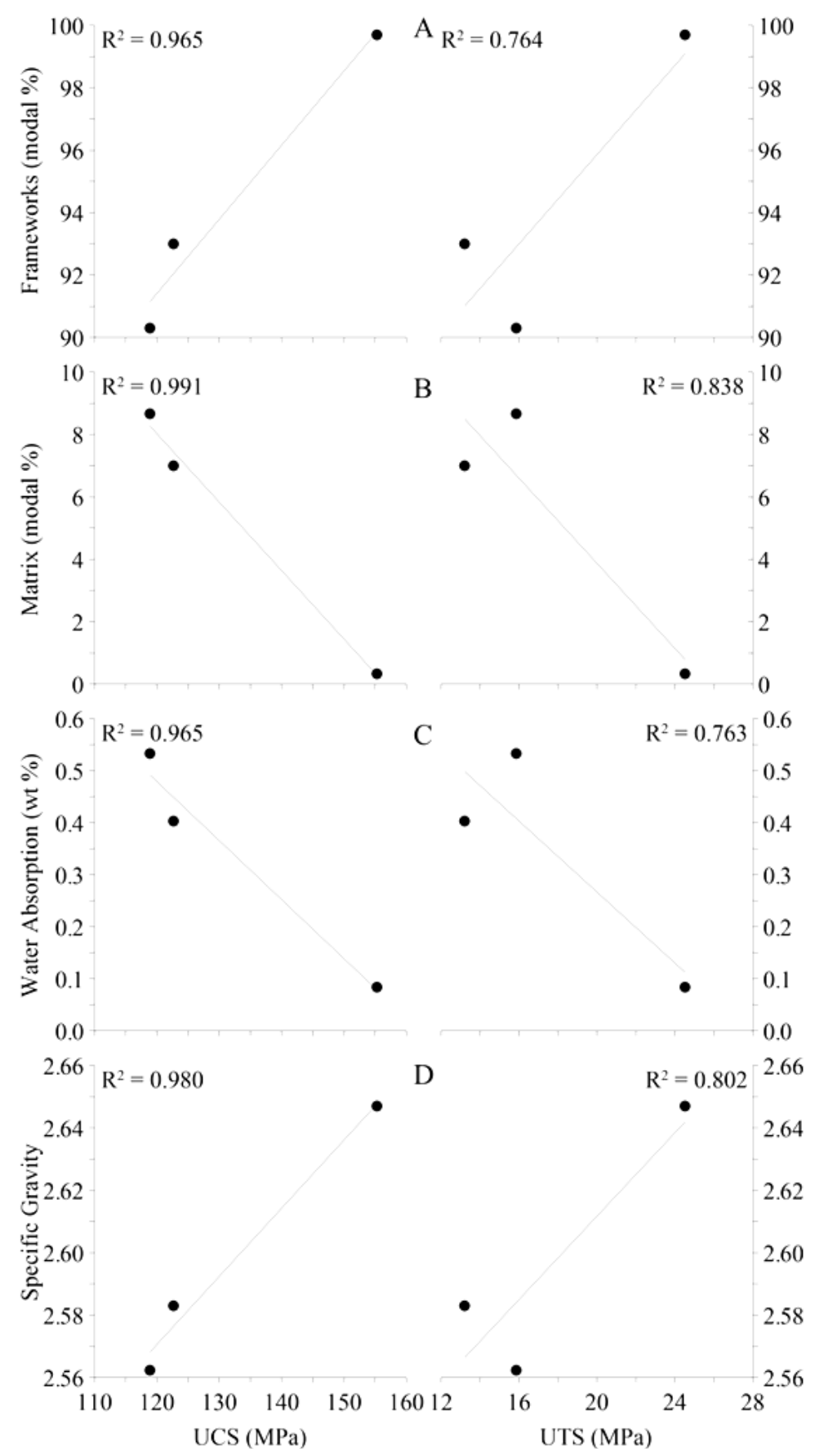

Figure 7. Variation of strength against modal composition and physical properties of the Tanawal and Misri Banda samples; all the plots are based on average values.

5) Despite containing less feldspar and hence displaying higher quartz to feldspar ratios, the strength values of the Tanawal samples are lower than the Misri Banda ones. This strongly suggests that the role of quartz to feldspar ratio in determining rock strength is less important than other petrographic features, especially the type and abundance of matrix.

\section{Acknowledgements}

The Department of Geology, University of Peshawar financed and facilitated the geological fieldwork, thin sec- 
tion making, petrographic investigation and sample preparation for geo-mechanical testing. Whereas the UCS and UTS were tested in the Material Testing Laboratory of the Department of Civil Engineering, University of Engineering and Technology, Peshawar, the water absorption capacity and specific gravity were determined in the Geochemistry Laboratory of the National Center of Excellence in Geology, University of Peshawar, Pakistan.

\section{References}

[1] Ori, G.G. and Friend, P.F. (1984) Sedimentary Basins Formed and Carried Piggyback on Active Thrust Sheets. Geology, 12, 475-478. http://dx.doi.org/10.1130/0091-7613(1984)12<475:SBFACP $>2.0 . C O ; 2$

[2] Di Pietro, J.A., Pogue, K.R. and Hussain, A. (1999) Geologic Map of the Indus Syntaxis and Surrounding Area, Northwest Himalaya, Pakistan. 14th Himalaya and Tibet: Mountain Roots to Mountain Tops, 328, 159-178. http://dx.doi.org/10.1130/0-8137-2328-0.159

[3] Pogue, K.R., Quade, J., Hussain, A., Hinz, N. and Write, H. (1999) Isotopic Constraints on the Age of Metasedimentry Rocks of the Peshawar Basin, Pakistan. 14th Himalaya-Karakorum-Tibet Workshop, 99, 117-118.

[4] Willard, R.J. and McWilliams, J.R. (1969) Microstructural Techniques in the Study of Physical Properties of Rocks. International Journal of Rock Mechanics and Mining Sciences, 6, 1-12. http://dx.doi.org/10.1016/0148-9062(69)90025-4

[5] Farmer, I.W. (1983) Engineering Behavior of Rocks. Chapman and Hall, London.

[6] Howarth, D.F. (1986) Experimental Study on the Relationship between Rock Texture and Mechanical Performance. Transactions of the Institute of Mining Metallurgy, 95, 41-44.

[7] Shakoor, A. and Bonelli, R.E. (1991) Relationship between Petrographic Characteristics, Engineering Index Properties and Mechanical Properties of Selected Sandstone. Bulletin of the Assoc Engineering Geologists, 28, 55-71. http://dx.doi.org/10.2113/gseegeosci.xxviii.1.55

[8] Fell, R., Graw, P., Stapledon, D. and Bell, F.G. (2005) Geotechnical Engineering of Dams. Taylor and Francis, London.

[9] Bell, F.G. (2007) Engineering Geology. 2nd Edition, An Imprint of Elsevier, Butterworth-Heinemann.

[10] Lindqvist, J.E., Åkesson, U. and Malaga, K. (2007) Microstructure and Functional Properties of Rock Materials. Material Characterization, 58, 1183-1188. http://dx.doi.org/10.1016/j.matchar.2007.04.012

[11] Treloar, P.J., Bronghton, R.D., Williams, M.P. and Khan M.A. (1989) Deformation, Metamorphism, and Imbrication of the Indian Plate South of the Main Mantle Thrust, North Pakistan. Journal of Metamorphic Geology, 7, 111-125. http://dx.doi.org/10.1111/j.1525-1314.1989.tb00578.x

[12] Yeats, R.S. and Lawrence, R.D. (1984) Tectonics of the Himalayan Thrust Belt in Northern Pakistan. In: Haq, B.U. and Milliman, J.D., Eds., Marine Geology and Oceanography of Arabian Sea and Coastal Pakistan, Van Nostrand Reinhold, New York, 177-200.

[13] Pogue, K.R., Wardlaw, B.R., Harris, A.G. and Hussain, A. (1992) Paleozoic Stratigraphy of Peshawar Basin, Pakistan: Correlations and Implications. Geological Society of America Bulletin, 104, 915-927. http://dx.doi.org/10.1130/0016-7606(1992)104<0915:PAMSOT>2.3.CO;2

[14] Hussain, A., Pogue, K.R., Khan, S.R. and Ahmad, I. (1991) Paleozoic Stratigraphy of the Peshawar Basin. Geological Bulletin (University of Peshawar), 24, 85-97.

[15] ASTM D-3976 (1986) Standard Test Method for Splitting Tensile Strength of Intact Rock Core Specimens. American Society for Testing Material, Philedelphia.

[16] ASTM C-97 (1977) Test for Absorption and Bulk Specific Gravity of Natural Building Stones. American Society for Testing Material, Philedelphia.

[17] Sajid, M., Arif, M. and Muhammad, N. (2009) Petrography and Engineering Properties of Rocks from Khagram-Razagram Area, Lower Dir District, NWFP, Pakistan. Journal of Himalayan Earth Sciences, 42, 25-36.

[18] Anon (1977) The Description of Rock Masses for Engineering Purposes. Engineering Group Working Party Report. Quaternary Journal of Engineering Geology, 10, 43-52.

[19] Arif, M., Bukhari, S.W.H., Muhammad, N. and Sajid, M. (2013) Petrography and Physicomechanical Properties of Rocks from the Ambela Granitic Complex, NW Pakistan. The Scientific World Journal, 2013, Article ID: 349381. http://dx.doi.org/10.1155/2013/349381

[20] Blyth, F.G.H. and De Freitas, M.H. (1974) A Geology of Engineers. ELBS and Edward Arnold, London, 514.

[21] Dott, R.H. (1964) Wacke, Greywacke and Matrix - What Approach to Immature Sandstone Classification? Journal of 
Sedimentary Petrology, 34, 625-632.

[22] Pettijohn, F.J., Potter, P.E. and Seiver, R. (1987) Sand and Sandstone. Springer-Verlag, New York.

[23] Malik, M.H. and Rashid, S. (1997) Correlation of Some Engineering Geological Properties of the Murree Formation at Lower Topa (Murree District), Pakistan. Geological Bulletin (University of Peshawar), 30, 69-81. 